\title{
Collective Farming System as Group Cooperation in the Perspective of Islamic Economic Value
}

\author{
Siti Yusi Rusimah \\ Department of Agribusiness \\ Faculty of Agriculture UMY \\ Yogyakarta, Indonesia \\ sitiyusirusimah@umy.ac.id
}

\author{
Lestari Rahayu \\ Department of Agribusiness \\ Faculty of Agriculture UMY \\ Yogyakarta, Indonesia \\ lestari_rahayu@umy.ac.id
}

\author{
Sriyadi \\ Department of Agribusiness \\ Faculty of Agriculture UMY \\ Yogyakarta, Indonesia \\ sriyadi@umy.ac.id
}

\begin{abstract}
One of the fish farmers' groups in Tasikmalaya, West Java, GiriRaharja has succeeded as the winner of the national competition. This group used collective farming system as an effort in increasing farmers' welfare. This research aimed to describe how the farmers' group has developed a collective farming system culturally close to Islamic values. Primary data were collected by participation observation in the activities of group and community. Some in-depth interview was also done with group administrator, group member, and nonmember as informants. The result showed that collective farming system was developed by combining the farmers land area for fish cultivation using the environmentally friendly technology in an integrated business system. The collective farming system has been designed based on universal values, especially justice and distribution of benefits among the people. This is the similar to sharia financing schema based on Islamic values in business transaction. The farmers did not realize that transaction in the collective farming system is identical with sharia finance schemes, such as Murabaha, Mudaraba, Ijarah, and Rahn. It is recommended to develop a collective farming system based on sharia in community that keeps anti-usury Islamic values
\end{abstract}

Keywords - collective farming system, farmers' group, fish cultivation technology, Islamic values, sharia financing schema.

\section{INTRODUCTION}

Fisheries is an agricultural sub-sector that is getting more attention, given its strategic role in providing animal protein sources for all people [1]. The consumption of fish as protein source has increased rapidly in Indonesia, reaching $16.7 \%$ per year. However, it is still dominated by consumption of marine fish rather than freshwater fish that in fact is a potential source in Indonesia. With the management using sustainable technology, it is believed that freshwater fish production can be better and more productive than marine fish production.

Tasikmalaya is known as a center for freshwater fish production in the West Java region with production reaching 11,582 tons or Rp. 115.5 billion per year [2]. Cultivated on sandy land in clear and flowing water conditions, the fish product from Tasikmalaya has a number of typical characteristics that have a high bargaining position. So far, the market of fish production, due to the ability of fish production still under capacities, especially for Nila and Gurame [3], has only reached three cities, namely Bandung, Garut and Majalengka for consumption fish; and East Priangan for seed marketing.

To increase production and productivity, the government has developed the farmer's groups in the business organizations form. GiriRaharja is one of the groups that has gained trust to be the communityfish-hatchery unit (CHU), specifically for the NilaNirwana fish. The government chose this group as CHU for its success as the First Winner in the Mina Bahari National Competition [4,5]. GiriRaharja chose a system of collective farming in developing its business as a community fishhatchery unit (CHU).

Collective cooperation has developed in the production, processing, and marketing to improve market access and farmers' income [6], especially to develop market innovations [7] in various European countries. Collective system in rice production is also used as the tradition by the farmers in the Mekong Delta, Vietnam since the French colonial era [8]. Similarly, GiriRaharja in general uses the collective farming system as an effort to increase farmer productivity and income. However, in GiriRaharja this system has been developed based on the traditional values of the community which are close to Islamic values, especially those that tend to anti-usury

This paper reveals the group's role as a community fishhatchery unit (CHU) through a collective farming system and the similarity of business transactions in this system with Islamic values. From this research, it is expected to develop a model of sharia-based group cooperation. This model is useful to socialize the sharia financing schemes in traditional communities that tightly hold the anti-usury values.

\section{METHODS}

Researchers used a qualitative approach with a description analysis method to explain the phenomenon of group cooperation using the collective farming system. The focus of this study was to analyze the system suitability with Islamic economic values. The research was carried out in GiriRaharjaFarmers's Group inTasikmalaya Regency. GiriRaharja is a group that has a rapid development in which within the four-year period since its establishment in 2010, it managed to be the champion of national competition in 2014 and chosen as the community fish-hatchery unit (CHU) in West Java.

Primary data were collected from the farmers as group administrators ( 8 persons), group members ( 8 persons), and group partners ( 2 persons); and 2 persons from traders, investors, and the fisheries office. The group administrator informants consisted of three active and inactive, and two old administrators. Whereas, the group member informants consisted of two active, inactive, new and old members. The number of informants was not determined from the begining of the study, but it was adjusted to the needs. If there was no new information to explain the phenomenon under study, the number of informant was

In-depth interviews were done with the informants in collecting the information related to the implementation of 
collective farming system and its compatibility with Islamic economic values. Moreover, researcher got involved in each group activity, both group meetings, and activities in the field ranging from pool cleaning, feeding, harvesting, and shipping of goods. Harvesting were the heaviest activities carried out by researchers, because researchers had to be in the pond from the morning until midday with the body under water. However, in this way, the researchers were able to find out what actually happened in group dynamic.

Data analysis was carried out since searching and compiling information and facts obtained from interviews, field notes, and documentation. Data were analyzed by organizing data into categories, describing it into units, synthesizing, composing into patterns, choosing which was important and what would be learned, and making conclusions [9]. Data analysis was conducted inductively, started from collecting and studying empirical facts in the field, reducing data, displaying data and verifying in concluding [10]

\section{RESULTS AND DISCUSSION}

Results and Discussion contain the result of data analysis but not containing raw data or print-screen of analysis) presented in table or figure. Sufficient and comprehensive data should be presented to give complete information and allow the reader to interpret the results. The text should explain or elaborate the tabular data, but numbers should not be repeated extensively within the text. Discussion should be consistent, interpret the results clearly and concisely, and logically address mechanism and explanation, supported with suitable literatures. The discussion should show relevance between the results and the field of investigation and/or hypotheses.

\section{A. Collective Farming System}

As a community hatchery unit (UPR) in West Java, GiriRaharja Farmers' Group chose a collective farming system in carrying out the responsibility of providing Nirvana tilapia seeds, for the East Priangan region. The group develops a collective farming system through land incorporation, application of standard cultivation technology, and integrated business system development. In a collective farming system, the land incorporation and the application of standardized technology are important as an effort to increase productivity [11]

\section{1) Incorporating Land}

The group manages 2,375 Ha land, consisting of 2,235 Ha land belonging to group members rented by the group, and $0.14 \mathrm{Ha}$ land controlled by the group with pawning status. Of the total combined land, the group utilizes $0.5 \mathrm{Ha}$ for seed pond cultivation, and has built a meeting place and a feed warehouse. Furthermore, the group gives the members an opportunity in managing remaining land to cultivate tilapia in seeds production or for consumption product.

\section{2) Application of Cultivation Standar Technology}

To meet the market demand, the group chose a monoculture system with three cultivation systems, namely pond cultivation, second plants (palawija), and combining farming (mina-padi). Every farmer, either as the member or as the nonmember group, may choose any cultivation system to be cultivated in a condition that it still based upon the following group's technology standards: i) the group only accepts Nirvana Tilapia production; ii) cultivation must be carried out in a monoculture manner; iii) the group should use a semi-intensive maintenance system (utilizing natural feeds and a little factory feed)production; iv) cultivation must be carried out in a monoculture manner; and v) the group uses a semi-intensive maintenance system (utilizing natural feed plus a little factory feed)

\section{3) Integrated Business System}

The choice to produce Nila Nirvana is due to the consideration that this fish has a typical Wanayasa taste. Nila Nirvana is the result of a crossover selection of GIFT and GET Tilapia from the Philippines conducted at the Wanayasa Fish Seed Development Center, Purwakarta, West Java, and it launched in 2006. This type of fish has become the primary cultivated commodity, either in fish production for seeds or ready for consumption. In this production, the group has provided seeds and feed, and bought the members' fish at higher price than the traders do at the production site.

\section{B. Islamic Economic Values in Collective Farming System}

The collective farming system developed by the GiriRaharja group contains some values close to Islamic teachings. The closeness of the collective farming system with Islamic values can be seen from the development of Tilapia production businesses that is in line with the principles of Islamic economic value and the suitability of the cooperation system developed with the Sharia financing schemes [12]. Referring to the economic value of Islam, any activities should be based on the values of the broad society economy, justice, income distribution, and individual freedom [13].

\section{1) Broad Society Economy}

Products produced in the form of fish ranging from larvae, fish seeds and fish for consumption as the products needed by the broader community, both fish farmers, producers, industrial consumers, and household consumers. Consumption fish is a food that is believed to be healthy, safe and containing nutrients needed by people of various ages from children, adolescents, adults to adults. Tilapia is a type of fish that is affordable, so the demand on it is relatively higher than other types of fish.

2) Income Distribution

Table 1 shows that the collective farming system provides some opportunities for group members and other communities to be involved in group business activities as resources owner. As landowners, the farmer members combine their land to be managed by the group, so that they get a share of the group's business results. As the owner of labor and time, members can work in a variety of fish farming business activities ranging from organizing ponds, planting, maintaining, harvesting, marketing, or managing ponds independently. Islamic teachings have some instruments to ensure the distribution of wealth in the community [14]. 
Table 1. People participation and their income

\begin{tabular}{|c|c|c|c|}
\hline \multirow[t]{2}{*}{ No. } & \multicolumn{3}{|c|}{ Participant } \\
\hline & $\begin{array}{l}\text { Part of } \\
\text { Community }\end{array}$ & Participation & $\begin{array}{l}\text { Source of } \\
\text { income }\end{array}$ \\
\hline \multirow[t]{7}{*}{1.} & Member of group & Land merger & Income share \\
\hline & & Marketing & Wage per $\mathrm{kg}$ \\
\hline & & Harvesting & Wage per kg \\
\hline & & Feeding & Wage per day \\
\hline & & $\begin{array}{l}\text { Cleaning the } \\
\text { pond }\end{array}$ & Wage per day \\
\hline & & Making pond & Wage per day \\
\hline & & Fish producer & Income \\
\hline \multirow{3}{*}{$\begin{array}{l}2 . \\
3 .\end{array}$} & Non-member & Fish producer & Income \\
\hline & Land owner & $\begin{array}{l}\text { combining } \\
\text { farming }\end{array}$ & Value added \\
\hline & & $\begin{array}{l}\text { Second } \\
\text { Plants }\end{array}$ & Value added \\
\hline 4. & Investor & Investation & Income share \\
\hline 5. & Other people & Feed trader & Profit \\
\hline
\end{tabular}

\section{3) Fair Distribution}

Fair distribution among the involved actors is relative. However, the agreements recorded in the employment contract and the transparency of the activities and results of the group's business are the basis for upholding justice in business cooperation. Each party involved knows what activities or roles they are carrying out. Which party provides the means of production, which party bears the risk, who will market the results, and what is its right have been stated in an agreement (Table 2). In Islamic principles, justice is the central value that forms the basis of every action [15] and is the primary criterion for Islamic economics [16].

\section{4) Individual Freedom}

Fish farming is prone to environmental pollution if using intensive feeds. However, the group has used the natural food as a primary feed and a little number of pellets for stimulating the fish appetite. The use of animal manure with the technique of making feed holes, the utilization of combining farming or minapadi and second plants or palawija systems has saved a lot of use of pellet feeds The excessive use of pellets can cause the pond's water dirty, and when it has flowed into the waters it will accelerate the growth of weeds, thus disrupting the waterways.

Table 2. The agreements between group and others

\begin{tabular}{lllll}
\hline & \multicolumn{3}{c}{ Agreements of Group } \\
\cline { 2 - 5 } $\begin{array}{l}\text { Business } \\
\text { Activities }\end{array}$ & $\begin{array}{l}\text { Seed-fish \& } \\
\text { consumption } \\
\text { production }\end{array}$ & $\begin{array}{l}\text { Seed-fish \& } \\
\text { consumption } \\
\text { production }\end{array}$ & $\begin{array}{l}\text { Second } \\
\text { plants } \\
\text { and } \\
\text { combing } \\
\text { farming }\end{array}$ & Hatchery \\
Asset & $\begin{array}{l}\text { Labor and } \\
\text { management }\end{array}$ & $\begin{array}{l}\text { Labor, } \\
\text { management, } \\
\text { capital }\end{array}$ & Land & $\begin{array}{l}\text { Brood- } \\
\text { stock }\end{array}$ \\
Feed & Group & Partner & Group & Group \\
Risk Taker & Group & Partner & Group & Group \\
Marketing & Group & Group & Group & Group \\
Income & $90 \%$ & $\begin{array}{l}100 \% \\
\text { income }\end{array}$ & Value \\
added & turnover \\
\hline
\end{tabular}

\section{The Alignment of Collective Farming System Transaction with Sharia Financi Schemes}

Business transactions that occur in the collective farming system have some similarities to the shari'a financing scheme, which is to avoid usury. Riba is the primary element of capitalist economy which is prohibited in islamic teachings because it is far from the value of justice [17]. The analysis of the alignment of business transactions in the collective farming system with the shari'a financing scheme is shown in Table 3.

Table 3. Similarities and differences bussines transaction in collective farming and finance institution schema

\begin{tabular}{|c|c|c|c|}
\hline Skema & $\begin{array}{c}\text { Collective } \\
\text { farming } \\
\text { transactions }\end{array}$ & Similarities & Differences \\
\hline Murabahah & $\begin{array}{l}\text { The group } \\
\text { buys fish } \\
\text { produced by } \\
\text { members or } \\
\text { partners with } \\
\text { delayed } \\
\text { payments }\end{array}$ & $\begin{array}{l}\text { Buying and } \\
\text { selling can be } \\
\text { done through } \\
\text { credit } \\
\text { payments }\end{array}$ & $\begin{array}{c}\text { When payment } \\
\text { is not } \\
\text { determined, } \\
\text { there is no } \\
\text { clarity when the } \\
\text { item will be paid }\end{array}$ \\
\hline Mudharobah & $\begin{array}{l}\text { Group as a the } \\
\text { provider of } \\
\text { production } \\
\text { facilities with } \\
\text { members as } \\
\text { managers }\end{array}$ & $\begin{array}{l}\text { The group } \\
\text { provides funds } \\
\text { and gets } 10 \% \\
\text { share of the } \\
\text { results of } \\
\text { managed by } \\
\text { members } \\
\text { operations }\end{array}$ & $\begin{array}{c}10 \% \text { profit } \\
\text { sharing is } \\
\text { conceptualized } \\
\text { as member dues, } \\
\text { there is no } \\
\text { clarity of } \\
\text { contract money }\end{array}$ \\
\hline Musyarokah & $\begin{array}{l}\text { Groups as } \\
\text { managers and } \\
\text { providers of } \\
\text { production } \\
\text { facilities with } \\
\text { investors } \\
\text { providing } \\
\text { broodstock }\end{array}$ & $\begin{array}{l}\text { There is an } \\
\text { agreed profit } \\
\text { sharing at the } \\
\text { beginning, } \\
\text { namely the } \\
33 \% \text { group and } \\
30 \% \text { investors }\end{array}$ & $\begin{array}{l}\text { The risk is borne } \\
\text { by the group, it } \\
\text { must be borne } \\
\text { together in } \\
\text { accordance with } \\
\text { completing } \\
\text { capital }\end{array}$ \\
\hline Rahn & $\begin{array}{c}\text { Group as } \\
\text { lenders with } \\
\text { farmers as land } \\
\text { owners }\end{array}$ & $\begin{array}{l}\text { The mortgage } \\
\text { is worked on } \\
\text { by the group } \\
\text { with a profit } \\
\text { sharing system }\end{array}$ & $\begin{array}{l}\text { There is no end } \\
\text { time term for } \\
\text { borrowing }\end{array}$ \\
\hline
\end{tabular}

1) Murabaha

Murabaha is a sale of goods by stating the cost and profit (margin) agreed upon by the seller and the buyer. The payments for the sale and purchase can be made in cash or credit. In collective farming system there are various transactions close to Murabaha. This transaction is between the group as the buyer and the farmers as the seller, or between the group as the seller and the trader as the buyer. In the Sharia financing schemes, such transactions are not prohibited, but have no elements of gharar (uncertainty) regarding quantity, quality, price and time. Buying and selling transactions that occur in the groups have fulfilled the certainty of quantity, quality, and price. The price has been set transparently and is known to all parties; the group only receives products that have already been sorted so that the quality is guaranteed, and sales are carried out by weighing, not using selling system while the fish is still in the pond. However, there is still uncertainty about payment because the group will pay the farmers if they have received the payments from other buyers. Hence, Murabaha transactions carried out by the group still contains the ghararregarding payment time. However, the sale and purchase transaction is still more in line with the MUI 
Fatwa, compared to murabahapractices mostly carried out by sharia financial institutions. In that transaction, the buyer does not receive the goods, but money.

\section{2) Mudharabah}

Mudhorobah is a collaboration between funders (shohibulmaal) and business managers (mudhorib). Related with this term, group acts as a funder by providing seeds and feed, while the members act as business managers. Group has the right to get $10 \%$ of the farmer's income. In this collaboration, both parties face the farming risk. When farmers experience a crop failure, farmers do not need to pay the price of seeds and feed that is group risk. This system is very suitable with the mudharabascheme in sharia financing. The use membership fees, which have been practiced so far, can raise a problem to farmers. A part of farmers often asks questions why members have to pay contributions, while nonmembers do not have to pay anything. The contribution term should be replaced with profit sharing term for group as its contributions to provide seeds and feeds and maintain the environment and security. While cooperation with partners included in a trade contract, partners buy seeds from the group and sell the results to the group; so there is no need to share their income with group.

\section{3) Pawn (Rahn)}

Pawn (Rahn) is a money lending transaction with collateral in which in the sharia financing scheme is it is included in a transaction with tabarru or virtue contract. It means that in the transaction there should be no profit taken by the lender [19]. In transactions carried out by groups, two things need to be straightened out, namely: (1) liens should not associate with utilization rights; (2) the loan period should set, so that this transaction is free from gharar (uncertainty concerning time). However, sharia banking also uses to combine Rahn (pledge) schemes with schemes such as ijarah to gain profit $[20,21,22]$.

\section{CONCLUSION}

The collective farming system developed by the GiriRaharja group runs effectively seen from the merging of land in supporting NilaNirwana hatchery, the development of feed-saving technology, and the occurrence of business integration. The effort developed by the group has fulfilled Islamic economic values as it has produced some products that are needed by the community, involved many parties, developed explicit agreements and a transparent administration system; and used environmentally friendly technology. Most of the transactions developed by group are similar with the sharia financing principles such as Murabaha, Musyarokah, Mudhorobah, and Rahn. However, some improvements are needed, so that transactions are indeed under sharia principles. The payment time in Murabaha and loan repayment time in Rahn must be determined. Membership dues can conceptualize as profit sharing for group contributions in the supply of seeds, feed, provision of ponds, and maintenance of cleanliness and environmental security. The proportion of the share of profits to investors should be towards income rather than revenue bullets.

\section{ACKNOWLEDGMENT}

Thank for the financial support from the LP3M Partnership Program, Muhammadiyah University of Yogyakarta. Thanks are also extended to Ade IlhamZakaria and FadhilaNajmiHikmat for their hard work in collecting data in the field.

\section{REFERENCES}

[1] Saparinto C \& Rini S. Success in Nila Fish Cultivation (in Indonesia).Yogyakarta: Lily Publisher; 2011

[2] Marine and Fisheries Extention Education Center. Guide to Growing and Developing the Main Actors of Fisheries Institutions (In the 2012 Deconcentration of Marine and Fisheries Extension Activities). Ministry of Maritime Affairs and Fisheries: Jakarta; 2012

[3] Tasikmalaya Regency Government. Investment Profile of Tasikmalaya Regency 2012. (Online). 2012 (Cited in 2015 Jan 10); Available from: URL: http://tasikmalayakab.go.id.

[4] Pikiran Rakyat. Giri Raharja Sukaratu Nominated as the Nasional Champion of Nila Cultivication (Online). 2015 (Cited in 2015 Jan 10)

[5] Latif, A. 2015. Giri Raharja Farmer's Group Change Cicurug Arja Become Nila Village. Kabar Priangan. Monday, 27 april 2015.

[6] Knickel K,Zerger C, Jahn G \& Renting H. Limiting and Enabling Factors of Collective Farmers' Marketing Initiatives: Results of a Comparative Analysis of the Situation and Trends in 10 European Countries. Journal of Hunger \& Environmental Nutrition. (Online). 2008 (Cited in 2018 August 4); Available from://www.tandfonline.com/loi/when20

[7] Schermer M, Renting H\&Oostindie H. Collective Farmers' Marketing Initiatives in Europe: Diversity, Contextuality and Dynamics. Int. Jrnl.ofSoc.ofAgr. \& Food, Vol.18, No.1, pp. 1-11. (Online). 2010 (Cited in 2018 August 4).

[8] Tuan LA, Cottrell A and King D. Changes in Social Capital: A Case Study of CollectiveRice Farming Practices in the Mekong Delta, Vietnam. Journal of Vietnamese Studies, Vol. 9, No. 2 (Spring 2014), pp. 68-99. (Online). 2014 (Cite 2018 August 4). Available from; URL: http://www.jstor.org/stable/10.1525/vs.2014.9.2.68

[9] Bungin B. Analisis Data Penelitian Kualitatif, Pemahaman Filosofis dan Metodologis Kearah Penguasaan Model Aplikasi. Jakarta: PT. Raja Grapindo Persada; 2003

[10] Sugiyono. Metode Penelitian Kuantitatif dan R\&D. Bandung: Alfabeta: 2013 Bandung.

[11]. Kannan. Collective Farming Kothamangalam Model: A new initiative. (Online). 2014 (Cite 2018 August 4); Available from: URL https://www.researchgate.net/publication/2773

[12] Yusoff MM. \& Aziz MRA. Shariah - Compliant Financing For Agriculture in IslamicBanking Institutions. World Bank Conference Paper - September 2013. UniversitiSains Islam Malaysia. (Online). 2013 (Cited in 2018 August 4).

[13] Antonio MS. Bank Syari'ah: dari teori ke praktik. Jakarta: Gema Insani: 2013

[14] Zia MD. \&Nasir-Ud-Din N. Islamic Economic Rationalism and Distribution of Wealth: A comparativeview. IOSR Journal of Business and Management (IOSR-JBM) Volume 18, Issue 4 .Ver. IV, PP 4352. (Online). 2016 (Cited in 2018 August 4); Available from:http://www.iosrjournals.org/

[15] Zaman HMF, Khan SK Ahmed M, Raja YM. 2015. Islamic Values and Ethical System towards Business: Does Islam Provide Best Framework to the Corporate World? International Journal of Economics, Commerce and Management 3(2). (Online). 2015. (Cited in 2018 August 4); Availablefrom:URL http://www.tandfonline.com/loi/when20

[16] Leaman O. Economics and Religion or Economics versus Religion: The Concept of an Islamic Economics. In Ames RT \&HershockPD. Value and Values Book: Economics and justice in an age of global. Hawai: University of Hawai'i Press. (Online). 2015. (Cite 2018 August 4); Available from: URL: http://www.jstor.org/stable/j.ctt13x1k8c.19 
[17] Arif M, Hussain A, Azeem M. Riba Free Economy Model. International Journal of Humanities and Social Science 2 (6) P-141 (Online). 2014. (Cite 2018 August 4).

[18] Nisa, A.F.. The Role of Baitul Maal Wat Tamwil in Increasing Farmers'welfare. Yogyakarta: Faculty of Agriculture UMY: 2014

[19] Hussain L \&Ali MM. Sharī ahNon-compliant Assets as Rahn (pledge) in Islamic BankingProducts: a fiqhī perspective. ISRA International Journal of Islamic Finance Vol. 9 Issue: 2, pp.196-199 (Online). 2013. (Cite 2018 August 4); Available from: URL: https://doi.org/10.1108/IJIF-08-2017-0018

[20] Khir MFA, Badri MB, Hussain L. Critical Appraisal of Rahn-based Islamic Microcredit Facility FromShari'ah Perspective. Advances in Natural and Applied Sciences, 7(3): 221-231. (Online). 2013. (Cited in 2018 August 4).

[21]. Yulianda WI \& Syaifullah M. Practical of Syariah Pawn (Rahn) In Fatwa of National Shariah Board -Indonesia Ulama Council (Case Study at Syariah Indonesia National Bank (Bni). International Journal of Scientific \& Technology Research 7(1). (Online) 2018. (Cited in 2018 August 4); Available from:www.ijstr.org.

[22]. Hussain L \& Ali MM.Sharī ah non-compliant assets as rahn (pledge) in Islamic banking products: a fiqhī perspective. ISRA International Journal of Islamic Finance, Vol. 9 Issue: 2, pp.196-199. (Online) (Cited in 2018 August 4); Available from: URLhttps://doi.org/10.1108/IJIF-08-2017-001 